\title{
Foreign Election Observers in Africa: Towards an Obligations-Based Approach
}

\author{
Dr. Daniel Chigudu \\ Postdoctoral Research Fellow at the University of South Africa, College of Economic Management Sciences, Pretoria \\ South Africa, 173 Bourke Street, 202 Melivanda Mucklenuek, Pretoria, South Africa \\ Email:danchigudu@gmail.com
}

\section{Doi:10.5901/mjss.2015.v6n1s1p272}

\section{Abstract}

This article reflects on efforts by African countries to employ election observation assessments through domestic and international observers based on the obligation to comply with public international law. There are mixed feelings among voters, politicians and civil society organisations about the objectivity of election observation reports. This paper argues that basing election observation reports on legal commitments from public international law using the obligations-based approach articulated by the Cater Centre may enhance objectivity. The study is a content analysis of the obligations-based approach and observation reports made in selected African countries. Results indicate contradictions on findings of the same election by different international observers. An integrated obligations-approach framework on election observation should be developed by the African Union, and other international bodies in Africa. This may strengthen voter confidence and improve electoral democracy in the continent.

Keywords: Foreign election observers, obligations-based approach, domestic observer

\section{Introduction}

This article reflects on efforts by African countries to provide for foreign election observation in order to promote credibility of electoral outcomes through a discussion on contemporary issues pertaining to election observation in Europe and Africa. An overview of an analytical framework developed by the Carter Center for assessing electoral processes against obligations in public international law is given. This approach is based on international legal commitments that countries have accepted freely (Carroll and Davis-Roberts, 2013). The obligations-based approach to observing and assessing elections is more objective and transparent. Carroll and Davis-Roberts (2013:87) contend that the approach;

"Provides the most promising avenue for fostering deeper consensus on the elements that comprise "international standards for democratic elections,' as well as the underlying assessment criteria used by observer groups."

The paper briefly discusses the role of foreign election observers in promoting democratic elections in Africa. The Carter Center's obligations-based framework is discussed and the last section focuses on the challenges in Africa due to foreign observer missions then conclusion recommendations.

\section{Foreign Election Observations}

It appears the practice of election observation is not new. The first recorded international observation being that of the general election in Moldavia in 1857 (Gray and Laanela, 2002).Election observation may have undergone considerable development and change, particularly over the past two decades. The United Nations (UN) gave rise to new expectations in the conduct of election observation. This was noticeable when it was involved in the conduct of elections in South Africa, Cambodia, Namibia and Nicaragua. Scholars and researchers have wondered what the purpose of such observation is, how it is conducted and what benefits, if any, emanate from it. It is worthwhile to question the importance of international election observation and whether it is a valid and reliable means of verifying that an election is legitimate and has been conducted with integrity. For many, election observation is perceived as being able to objectively and independently assess and report on the integrity or otherwise of the diverse elements of an electoral process.

The assessments may form the basis for validating or challenging the legitimacy of the government elected. Findings by an observer mission may impact positively or negatively on donors' commitments to a country or on its relationship with supranational organisations, such as the African Union (AU), Southern African Development Community (SADC), Council of Europe or the Commonwealth. In one way, international observers can inspire voter confidence in terms of the secrecy and integrity of the voting process and provide the opportunity to evaluate the political, social and 
legal environment in which the election is being conducted. In another way, a foreign election observer mission's presence gives undue legitimacy to an improper electoral process. Gray and Laanela (2002) argue that, observer missions also run the risk of contradicting each other as they differ on interpretations of the notion of 'free and fair' election. It is further argued that, at times observer missions have been criticised as biased, costly electoral tourists, arbiters and intruders of national sovereignty.

According to Beaulieu (2013) while there are strategic choices for domestic election observers, rather than changing the way they cheat, governments bent on cheating tend to invite those observer organizations less apt to criticize their election, since it has become increasingly common for governments holding elections to invite international observers to observe the election process, with the understanding that these observers will then issue public reports based on their observations. Some scholars acknowledge and offer as further evidence of the strength of the election observation norm, that many governments invite observers even when they plan to cheat. Beaulieu (2013) notes that intimately connected to the phenomenon of cheating governments inviting observers is the fact that, election observers have at times appeared quite hesitant to criticise elections. By contrast, Hyde (2011) argues that many individual actors chose to invite election observers precisely because it was a costly signal, meant to suggest a democratic commitment to international actors in a position to confer benefits.

However, for truly democratic states the decision to invite observers is relatively costless as observers would likely find little to criticise. It turned out to be advantageous to them than to those that pretended to be democratic. It becomes conspicuous that leaders who do not invite observers would be dismissed as undemocratic. Hyde (2007) suggests that, international actors now play a prominent role in the developing world, in domestic elections and other democratic processes. The involvement of international actors compel states to hold democratic elections and these actors directly engage in the electoral process through provision of technical assistance and funding or by sending teams of observers to observe elections. She argues that, international influence on democratization is receiving a small amount of scholarly attention although growing, while the international dimension is increasingly getting accepted as a relevant variable in theories of political transition. Hyde (2007:38) quotes Gleditsch and Ward in a study of the international diffusion of democratization, in which they "firmly reject the idea that institutional change is driven entirely by domestic processes and unaffected by regional and international events". There were no recorded cases of international election observation in sovereign states up until 1962 (Hyde, 2007).

From 2004 and beyond eighty percent of elections that were held in young democracies were under international observer missions. It became imperative that any developing country wishing to hold a legitimate election was expected to invite international election observers (Bjornlund, 2004). Carothers (1997) however points out that even though the record of election observation grew over time particularly in the 1990s with the intention to condemn fraudulent elections, it remains unknown whether international observers and monitors can really bring about cleaner elections. Hyde (2007) argues that, any cross-national study that attempts to examine the effects of international observers on state elections would be plagued by endogeneity problems. It would be very difficult to distinguish between an election that was clean due to the presence of foreign observers and one that would have been clean regardless of their presence. Despite the difficulty, recent empirical and theoretical research point to international observers as potentially significant actors in electoral democracy. Fearon (2011) argues that international observers' evaluation of an election facilitate popular enforcement of democracy by improving the probability of popular coordination in defense of democracy and that their reports may encourage the collective uprising of voters after a fraudulent election. Arguably, this may have the potential to lead to alterations in power even when elections are stolen.

Hyde (2007:40) notes that;

"Sovereign leaders of developing countries willingly invite international monitors to judge their elections. If election observation is costless to the state leaders who invite them, this action is easy to explain as a form of cheap talk. However, if election observers cause (cheating) incumbent leaders to gain fewer votes, the puzzle of why leaders invite observers is more interesting and speaks to the impact of international pressure on the behavior of state leaders"

\section{Foreign Observers and Election Fraud}

Although it is unlikely that election fraud can be eliminated completely international election observers may improve the quality of electoral governance and contribute to democratization. But Hyde (2007:42) argues that "One possibility is that observers have no effect on fraud. There are leaders, such as Robert Mugabe of Zimbabwe, who invite international observers and cheat

openly." Whether this has empirical evidence or not remains a subject for debate. International observer reports 
indicate various types of electoral manipulation. Most of these include military intimidation of voters, vote-buying schemes, manipulation of voter-registration lists, ballot-box stuffing, failure to distribute ballots to opposition strongholds, improper attempts to influence voters inside the voting booth, intentional inflation of the vote tallies, and in some extreme cases jailing of opposition voters.

According to Schedler (2002) there are a number of possible methods of electoral manipulation, which range from direct election-day electoral fraud such as ballot-box stuffing, to longer-term forms of electoral bias such as gerrymandering. Theoretically, international election observers could have a deterrent effect on any form of election fraud, but testing gerrymandering may be difficult. A study by Hyde (2007) indicates that international observers can reduce the corrupt behavior of election officials and other political processes with potential for corruption. The experiment which she used could be replicated using field experimental methods in order to determine if domestic nonpartisan observers have the same deterrent effect like foreign observers. Apart from deterring electoral fraud on election day the presence of foreign observers may provide the incentive for some states to use methods of cheating that are less likely to be detected by international observers. Examples include manipulating the election well in advance of election day.

According to Gray and Laanela (2002: 189),

"With so much at stake-notably domestic legitimacy and international recognition-in the 'stamp of approval' that successful elections provide, a minor industry has developed in tandem with the proliferation of elections: election observation and monitoring. If the most favoured media image from high-profile elections, such as those in Kosovo, Cambodia, Peru, Indonesia and Zimbabwe, is the classic ballot box and the determined first-time voter, then the most favoured 'sound bite', competing with the actual results of the election, is their declaration as 'free and fair' or otherwise by high-profile personalities representing international observation groups."

\section{The Obligations-Based Approach}

Election observation must be done, measured and verified against generally understood principles, treaties and norms. Over the past two or three decades some of these principles have been developed based on experiences and practices of electoral events. These have been developed mainly by the international community, utilized and acknowledged as basis for providing guidance in determining the legitimacy and integrity of elections. The Carter Centre developed an obligations-based analytical framework for assessing electoral processes against obligations in public international law. This framework is based on international legal commitments that states have accepted freely and is more transparent, objective, and acceptable to host countries (Carroll and Davis-Roberts; 2013) The obligations-based framework appears to provide a plausible avenue for entrenching deeper consensus on the basic elements that comprise international standards for democratic elections and the underlying assessment criteria used by observer groups. Countries have accepted some obligations under public international law regarding democratic governance of elections by signing and ratifying international treaties or instruments from which the obligations framework was developed.

This approach can reassure host governments objectivity and transparency and helps to address concerns about professionalism and impartiality of observer missions. Carrol and Davis-Roberts (2013) report that, the Carter Center worked with a group of experts and collaborating organizations over a two-year period to review more than 200 source documents in public international law. These documents were relevant to various aspects of the electoral process. Twenty-one obligations were identified and direct text quotations compiled from the relevant passages of the source documents into a comprehensive compendium. The 21 obligations are summarized in Figure 1 below: 
The free expression of the will of the people - The popular will, freely expressed through genuine elections, must be the basis for legitimate political authority.

Genuine and periodic elections - Twin obligations requiring that elections must provide a real choice and be held at reasonable intervals, in a context that protects other fundamental rights.

The state must take necessary steps to ensure rights - States must take the steps necessary, in both law and practice, to give effect to fundamental rights.

The rule of law - The principle of the rule of law, implicit in international human rights law, is an essential condition of the fulfillment of rights.

Universal suffrage - The state should ensure that the broadest pool of voters is eligible to cast ballots, only restricted on the basis of reasonable and objective criteria.

Equal suffrage - The weight or value of the votes of eligible voters should be equal.

Secret ballot - Voting by secret ballot is recognized as critical for protecting free expression.

Prevention of corruption -States should take steps to prevent corruption, including through the promotion of transparency measures.

Every citizen has the right to participate in public affairs - Citizens have the right to participate in public affairs, including through civil socicty activities.

Every citizen has the right to vote - Citizens have the right to vote, only restricted on the basis of objective and reasonable criteria.

Every citizen has the right to be elected - Citizens have the right to be elected, only restricted on the basis of reasonable and objective criteria.

Freedom of assembly - Everyone has the right to assemble, including candidates and voters, during campaigns. Restrictions must be prescribed by law and "necessary in a democratic society." Freedom of association - Everyone has the right to free association, including the establishment of political parties and other organizations. Restrictions must be prescribed by law.

Freedom of movement - Everyone has the right to free movement, and any restrictions on that right must be proportionate to the interests it is intended to protect.

Equality before the law and absence of discrimination - States are obligated to ensure equality before the law and prevent discrimination in the exercise of rights and freedoms.

Freedom of opinion and expression - Everyone has the right to freedom of expression, including the communication of information between voters and candidates and to contribute to campaigns. Access to information - Everyone has the right to seck and receive public information, helping to provide transparency in the electoral process.

Right to security of the person - Everyone has the right to security of the person, including protection from arbitrary arrest, detention, and exile. This includes protection of voters, candidates, poll workers, and observers from coercion or intimidation.

Right to an effective remedy - States are obligated to ensure an effective and timely remedy by a competent administrative, legislative, or judicial authority, including during an electoral process. Right to a fair and public hearing - Everyone has the right to a fair and public hearing, with cases heard publicly and expeditiously by an impartial tribunal.

Fig.1. Public international law obligations for democratic elections: Adopted from Carroll and Davis-Roberts (2013; 90)

Foreign observer missions report their findings on obligations from treaties ratified by host countries only but it is worthwhile for them to consider the full body of international law in their assessments. The obligations referenced above constitute the various parts of the electoral process in its entirety. The obligations framework was developed using the 1948 Universal Declaration of Human Rights and the 1966 International Covenant on Civil and Political Rights as main source documents. These documents provide for rights of citizens in the expression of their will during periodic elections. While the concept of free and fair is pivotal to the work of foreign election observers, there is no one clear definition and methodology regarded as universally enabling an uncontestable judgement of the freeness and fairness of an election. The obligations-approach framework is an attempt to bridge this gap and provides a semblance of objectivity. Gray and Laanela (2002) contend that, identifying and codifying good practice, in determining the degree of 'prescriptiveness' and specificity that is possible or desirable in a field that has developed in such a diversified manner has not been without its challenges.

In most cases an election management body invites international observer missions or the host country can do so in pursuit of legitimacy. The invitation alone may not suffice in some instances.

The International Institute for Democracy and Electoral Assistance (IDEA) provides some prerequisites for determining involvement as detailed below:

- a basic agreement with the host country, which would include not only an

- official invitation but also general support from other parties and other groups

- an initial assessment of the likely character of the election, taking into consideration

- the existence of basic laws and freedoms, the legal framework for the elections 
- and the credibility of the election authorities; and

- a realistic assessment of whether the observers will be free and able to do their

- job.

Prerequisites alone may not enhance the observation unless the observer group is adequately resourced, well informed and prepared to carry the task. This helps to build the credibility of the observer mission.

\section{Professionalism and Codes of Conduct}

According to the International IDEA Code of Conduct for the Ethical and Professional Observation of Elections, election observation involves supervising and certifying the validity of all or some of the steps in an election process. This requires a high degree of professionalism. The United Nations, and other international organisations such as the European Union (EU), the Organization of American States (OAS), the Centre for Electoral Promotion and Assistance Commonwealth Secretariat, the guidelines for African Union Electoral Observation and Monitoring missions and the SADC Election Observer Missions (EOMs) and have put in place formal guidelines and codes of conduct which international observers are using.

\section{Challenges in Africa}

Gray and Laanela (2002) argue that election observation faces the challenge of closing the gap between ideal and practice as with many other human endeavours. While comprehensive guidelines and protocols have been developed election observation remain subjected to many vagaries which can have a significant impact on its effectiveness.

\subsection{Political Interference}

Political interference and limited resources in Africa prohibit the best practices in election observation from being achieved. There seem to be over reliance on eminent persons like former heads of state, senior parliamentarians and senior diplomats to lead foreign observer missions. Given such a scenario, there is limited space for professionalism and technical competence of the observers resulting in findings that are less objective and more subjective. In June 2000 for instance, Zimbabwe held parliamentary elections in which different foreign observer groups made contradicting reports. The then Organization of African Unity (OAU) team announced that in general the elections were transparent, credible, free and fair'. This was supported by the leader of the Namibian Observer Mission who had this to say;

\footnotetext{
"I have not seen any objective individual who was ever to say with a straight face that 'I have observed irregularities, I have observed rigging of the election, I have observed intimidation of the voters'-that they've been prevented to go and cast their votes. I have not seen that".
}

The South African Parliamentary Observer team in concurrence reported the election to have been free and fair.

For the same election, the SADC Parliamentary Forum Observer reported that, "The climate of insecurity obtaining in Zimbabwe since the 2000 parliamentary elections was such that the electoral process could not be said to adequately comply with the Norms and Standards for Elections in the SADC region". The Commonwealth Observer Group concluded that "the conditions in Zimbabwe did not adequately allow for the free expression of will by the electors"

\subsection{Sponsors of Foreign Observer Missions}

Election observation findings can be affected by the governments and organisations that sponsor the groups as well as the preconceptions, skills and biases of individual observers. There are challenges raised with respect to elections observed by the Southern African Development Community as noted by Mostamai (2013:3) who reports a;

"perceived failure of SADC Election Observation Missions (EOMs) to better institutionalize democratic governance inbetween and post elections in SADC member countries - with Zimbabwe (2008 and 2013), Swaziland (2008), Democratic Republic of Congo (2011) and Angola (2012) among those flagged as cases in point."

\subsection{Autocrats}

Other challenges in are reported by Beaulie and Hyde (2009:4) as, "Still, many electoral autocrats legitimized their rule 
through internationally observed elections, including Alberto Fujimori in Peru in 1995, Charles Taylor in Liberia in 1997, and Daniel arap Moi in Kenya in 1992"

\subsection{Lack of enforceable instruments}

The challenges that elections in Africa face need legally binding instruments to whip into line politicians in power who choose to ignore objective findings and recommendations made by international observers. Mapuva (2013:94) made this observation,

"Electoral observers, powerless as they are, have not helped the situation either, except to make recommendations which are in most cases binding and are ignored by political parties. Unless and until recommendations of election observers are taken seriously, electoral processes on the African continent will continue to be manipulated and trampled upon by powerful politicians."

\subsection{Power of the incumbency}

The domestic observers who complement efforts by foreign observers are in some cases politicians in disguise picked by incumbent governments to influence the political process. Those domestic observers who are non-state actors coming in the name of Faith Based Organisations (FBO) or Non-Governmental Organisations (NGOs) are either frustrated in the process of accreditation or their findings dismissed with contempt.

\subsection{Social factors}

Language and cultural factors if not taken care of properly by the foreign observer groups affect the findings and results.

\subsection{Lack of clarity on the phrase 'free and fair'}

International observers in Africa like SADC and AU tend to evaluate and validate the electoral process in a way by using terms like free and fair elections. This creates problems. The European Union Elections Observation Missions (EU EOMs), have abandoned this expression This could be an acknowledgement that there is no perfect election and that it is not the duty of foreign observers to validate an electoral process. The observer mission should just provide an impartial and genuine assessment with a view to addressing electoral flaws marked against international public law obligations. A briefing paper for the European Parliament cited in Tuccinardi, Balme and McCormack (2012:62) put it this way:

"After 15 years of international election observation, with increased awareness of election standards and observation methodology, subjective and simplistic "free and fair" statements have lost credibility. The particular problem with the "free and fair" formula is that it only allows a black/white evaluation, while the quality of an election is mostly in a grey zone between fully in line with international standards and fundamentally flawed"

\subsection{International best practice}

In Africa the concept of 'international standard' as yardstick for quality of an electoral process if pronounced by international organisations is often perceived as Western-oriented by the host countries(Tuccinardi et al;2012). Such standards are not seen as universal because they do not take account of both national and regional contexts. In view of that foreign observers' reports with such a term trigger automatic resentment. Tuccinardi et al (2012) argue that the world over there are no agreed standards implementing and regulating electoral processes since there is no form of democracy deemed superior to any other. Perhaps it is the reason why the Carter Center's Obligations-based approach is basically hinged on public international law largely borrowing from the 1948 Universal Declaration of Human Rights and the 1966 International Covenant on Civil and Political Rights. The fundamental freedoms and rights to be upheld must reside in Africa's international and regional treaties if foreign observer mission reports are to be taken seriously instead of giving blurred statements.

\section{Conclusion and Recommendations}

In light of the international observation challenges discussed above, the Carter Centre identified twenty-one obligations 
on democratic elections. The Centre assessed how each of these obligations impacts directly on observers' understanding of a constituent part of the electoral process. A big number of organisations are beginning to embrace this new approach to election observation. For supranational bodies it has become the basis developing election observation strategies and techniques that bridge the gap between international obligations and election implementation national laws for the host countries. The African Union may need to work in that direction for African states. Tuccinardi et al (2012:63) conclude that,

"This approach also demonstrates the synergies between election observation and election assistance, and how both can only make sense if offered in a spirit of partnership and cooperation in an attempt to support the host country, which has invited the observation and agreed to be scrutinized in order to meet its international obligations."

The challenges described above represent what obtains in most African countries. There is a need for a change in the conceptualization of foreign election observer mission and its assessment methods and adopt the obligationsapproach in order for international observation to remain a vibrant, relevant and democratic instrument. Assessments based strictly on obligations that are legally binding on host countries, make it mandatory for the countries to comply with regional and international treaties they subscribed to. This removes the impression of standards being imposed on them but to view foreign observers as playing a facilitator role to meet obligations which they signed for and ratified.

While domestic observer groups have had many setbacks like real or perceived political bias, poor reputation foreign observers remain the best alternative. Some local observers are perceived as being inspired by governments or opposition parties hence mere activists that are counterproductive. The work of domestic observers whether professional or not is often overshadowed by that of foreign observers.

\section{References}

Beaulie, E. a. (2009). In the Shadow of Democracy Promotion:Strategic Manipulation,International Observers and Election Boycotts. Comparative Political Studies, 42(3), 1-36.

Beaulieu, E. (2013). International Election Observers and the Democratic Quality of Elections. Election Law Journal, 12(1), 100-105.

Bjornlund, E. (2004). Beyond Free and Fair : Monitoring Elections and Building Democracy. Washington ,DC: Woodrow Wilson Centre Press.

Carol, J. a.-R. (2013). Carter Centre and Election Observation:An Obligations-Based Approach for Assessing Elections. Election Law Journal, 12(1), 87-93.

Carothers, T. (1997). The Obsevers Observed. Journal of Democracy, 8(3), 17-31.

Fearon, J. (2011). "Self-Enforcing Democracy. The Quarterly Journal of Economics, 126(4), 1661-1708.

Gleditsh, S. a. (2006, October). Diffusion and the International Context of Democratisation ". International Organisation, 60(4), 911-933.

Gray, B. a. (2002). International Election Observation. In T. a. Findlay (Ed.), Verification Yearbook (pp. 189-204). London, United Kingdom: VERTIC.

Hyde, D. (2011). The Pseudo-Democrat's Dilemma: Why Election Observation Became an International Norm. Ithaca,NY: Cornell University Press.

Hyde, S. (2007, October). The Obsever Effect in International Politics-Evidence from a natural experiment. World Politics, 60(1), 37-63.

Mapuva, J. (2013, July). Elections and Electoral Processes in Africa: A gimmick or a curse? African Journal of History and Culture, 5(5), 87-95.

Mostamai, D. (2013, October). SADC's 2013 Review of Its Principles and Guidelines Governing Democratic Elections: Need for Civil Society Input? Institute for Global Dialogue, 1-7.

Schedler, A. (2002). The Nested Game of Democratisation by Elections. International Journal of Political Science Review, 23(1), 103-22.

Tuccinardi, D., \& Balme, F. a. (2012). The Evolution of Election Observation in the European Union: From Fraud Prevention to Democracy Support. In I. IDEA, The Integrity of Elections: The Role of Regional Organisations (pp. 57-75). Stromsborg: International Institute for Democracy and Electoral Assistance. 